\title{
The perception of the journalist's profession in the context of fake news dissemination by official and social media
}

\section{Postrzeganie zawodu dziennikarza w kontekście rozpowszechniania fałszywych wiadomości przez media oficjalne i społecznościowe}

\author{
Dariusz Krawczyk* $^{*}$
}

\section{Abstract}

The majority (57\%) of Polish press, radio and TV journalists participating in a survey conducted in 2019 considered the dissemination of fake news to be a common phenomenon. The mass scale of this process was also noted by the majority $(88 \%)$ of communication experts participating in an international research project also carried out in 2019. The threat of misinformation has become one of the elements that shapes the perception of the profession's prestige by journalists, and also influences the selfesteem of professionalism. A comparison with surveys conducted in 2015 and 2016 showed that the percentage of journalists perceiving high (from $13 \%$ to $38 \%$ ) rather
\end{abstract}

\begin{abstract}
Abstrakt
Większość (57\%) polskich dziennikarzy prasowych, radiowych i telewizyjnych uczestniczących w ankiecie przeprowadzonej w 2019 r. uznało rozpowszechnianie fałszywych wiadomości za zjawisko społeczne. Masową skalę tego procesu zauważyła także większość (88\%) ekspertów ds. komunikacji uczestniczących w międzynarodowym projekcie badawczym przeprowadzonym również w 2019 r. Zagrożenie dezinformacją stało się jednym z elementów kształtujących postrzeganie prestiżu zawodu przez dziennikarzy. Wpływa ono także na samoocenę dziennikarską pod względem profesjonalizmu. Porównanie z ankietami przeprowadzonymi w $2015 \mathrm{r}$.
\end{abstract}

* Expert witness in the field of social communication and management; (e-mail: d. krawczyk@ elpress.pl): iD https://orcid.org/0000-0003-1823-0309. 
than low (from $7 \%$ to $17 \%$ ) social recognition for their profession increased significantly. However, their belief in a high level of professionalism decreased (from 60\% to $49 \%$ ), and the number of respondents reporting a noticeable lack of competence and substantive preparation among journalists (from $16 \%$ to $35 \%$ ) increased.

Key words: journalist, fake news, official media, social media, press, radio, professionalism i 2016 r. pozwoliło stwierdzić, że odsetek dziennikarzy postrzegających wysokie (z 13\% do 38\%), a nie niskie (z 7\% do $17 \%$ ), społeczne uznanie ich zawodu znacznie wzrósł. Jednocześnie ich przeświadczenie o wysokim poziomie profesjonalizmu spadło (z $60 \%$ do $49 \%$ ), a liczba respondentów - zgłaszających zauważalny brak kompetencji i merytorycznego przygotowania dziennikarzy w kontekście rozpowszechniania fałszywych wiadomości przez oficjalne i społecznościowe media - wzrosła (z 16\% do 35\%).

Slowa kluczowe: dziennikarz, fake news, media oficjalne, social media społecznościowe, prasa, radio, profesionalizm

\section{Introduction}

The aim of the article is to present a change in the perception of the journalist's profession based on a survey of journalists conducted in 2019, and its comparison with two similar analyses conducted in 2015 and 2016. The study may constitute a contribution to research on the condition of the journalistic environment in a situation in which the determinants of professionalism - craft, knowledge and ethics ${ }^{1}$ - are currently juxtaposed with the consequences of technological progress and political or social changes, as well as "the role of economic pressure, which affects the quality of Polish journalism and largely contributes to the erosion of journalism." 2 The social reputation of the profession is not only affected by factors directly resulting from the processes of the functioning of the media market, such as progressive and multifaceted convergence. The multimedia character of work, combined with employees' multitasking, undoubtedly influences the self-assessment of the profession. A new challenge for journalists and institutional entities in the media market, however, is the phenomenon of disseminating disinformation. The threat level verification, in this respect, was also the subject of statements by journalists who participated in the survey. The

1 J. OlęDZki: Polish Journalists: Professionals or Not? In: The Global Journalist. News People Around the World. Ed. D.H. Weaver, W. Wu. New York 1998.

${ }^{2}$ B. Dobek-Ostrowska, P. Barczyszyn, A. Michel: The Change in Journalism. Professional Culture of Polish Journalists (quantitative research)."Media Studies" 2013, No 1, p. 26. 
position of Polish journalists was juxtaposed with the opinions of participants in an international research project devoted to diagnosing the universality of fake news distribution and recommended forms of counteraction. In this context, the question was also posed whether the flood of manipulation in the communication space of official and social media is an opportunity or a threat to the traditional understanding of journalism. The journalists and communication experts who participated in the opinion polls were asked to determine the actual state of affairs in the perception of the profession's prestige, the professionalism of its representatives and the threat of misinformation. On this basis, the issue of the social reputation of journalists, the impact of spreading disinformation on the functioning of the media and the issue of journalistic diligence in the context of legal restrictions on freedom of expression were also discussed.

\section{The prestige of the journalist profession in the eyes of media market professionals}

A survey aimed at evaluating the social reputation of the journalist profession was conducted in 2019 among the employees of TV stations, radio stations, press publishers and Internet broadcasters. ${ }^{3}$ People employed in these editorial offices were asked to assess the prestige that, in their opinion, the journalist's profession in Poland currently enjoys. Most respondents expressed the opinion that the reputation of people connected with the world of media is average (44.4\% of responses). The next greatest percent was of respondents who were convinced of its high rating (38\%). The smallest percent was of those who believed there is a low level of social respect for their profession (17.4\%).

The next stage of the survey was to determine the changes in journalists' own perception of their profession. In this case, the largest group of participants expressed the opinion that the authority of the profession was growing (41.2\%). The second largest percent held that their prestige is decreasing (38\%). The remaining respondents $(20.8 \%)$ did not express a clear view on the subject.

${ }^{3}$ The research was carried out on 16th February 2019 in Zabrze during a community meeting of mass media employees with the participation of journalists from the following TV stations: TVP Info, TVN 24, TVN, Polsat News, TTV, Superstacji, Polsat, TVS, TVP3 Katowice, TVZ and TV Imperium, and journalists from the following radio stations: RMF FM, TOK FM, Jedynka (Polish Radio), Czwórka (Polish Radio), Polskie Radio24, Polskie Radio Katowice, Polskie Radio Kraków, Radio Piekary, Radio CCM, and Radio FEST. Also participating were press journalists from "Gazeta Wyborcza", "Super Express" and "Trybuna Górnicza". A total of 63 journalists took part in the author's research. 
When addressing the issue of competence to 'professionally practice a speciality $^{14}$, i.e. in the case of journalists, to deal with "editing, creating or preparing press materials's, respondents most often reported that journalists are professionally prepared for work ${ }^{6}$. This opinion was expressed by almost half of the respondents (49.2\%). About one third of respondents (34.9\%) presented the opposite view, claiming that journalists perform editorial duties in an inefficient, inexpert or dilettantish manner. The rest did not give a clear answer.

\section{Comparative analysis with test results obtained in 2016}

The obtained results should be compared with the results of a similar study conducted in 2016. At that time, about half of the respondents (51\%) claimed that journalists are professionals, while the percentage of respondents giving a negative assessment of their colleagues did not differ significantly from the results obtained in 2019 (34\%). Therefore, the belief that journalists possess appropriate qualifications did not undergo any fundamental change between the two studies.

On the other hand, in the 2016 study, the vast majority of respondents, when assessing the level of social approval and trust that journalists in Poland enjoy, claimed that it is 'average' (71\%). The second most frequent response was that their prestige is high (17\%), and the least frequent was that the prestige of the profession is low (11\%). The distribution of deposits in 2019 remained the same, but the proportions were reshaped. The responses positioning the perception of prestige in the 'medium' range decreased significantly, i.e. by 27 percentage points ( $44 \%$ in 2019 compared to $71 \%$ in 2016). The number of 'high' prestige responses increased radically by 21 percentage points (38\% vs. $17 \%$ ), and the number of responses assessing 'low' prestige increased by 6 percentage points (17\% vs. $11 \%)$.

Different trends were noted in the assessment of social transformations in the perception of journalists' prestige. The dominance of the pessimistic assump-

${ }^{4}$ Definition of the term "professionalism" in the Dictionary of the Polish Language PWN — https://sjp.pwn.pl (accessed: 6.03.2019).

${ }^{5}$ Pursuant to Article 7 of Act 2(5) — the Act of 26 January 1984, the Press Law Sets Out the Scope of the Journalist's Duties ("Journal of Laws" 1984, No 5, item 24).

${ }^{6}$ More on the professionalism of journalists and their professional culture: B. DobeKOstrowska: Polish Media System at the Crossroads. Media in Politics, Politics in the Media. Wrocław 2011, p. 23-62.

7 The author's research was conducted in Zabrze on 10th December, 2016. It involved 70 journalists from the local, regional and national press, regional and national radio stations, and TV stations and Internet broadcasters (regional and national centres of private and public media). The study covered various aspects of the profession and their influence on the perception of its prestige. 
tion that journalists' authority is decreasing (59\% in 2016) was replaced by the vision of growing esteem and respect (41\% in 2019). The change in mood is documented by the scale of the difference: responses claiming a positive social perception of the profession increased by 27 percentage points (from $14 \%$ to $41 \%$ ), while responses claiming a negative perception decreased by 21 percentage points (from $59 \%$ to $38 \%$ ).

\section{Comparative analysis with test results obtained in 2015}

A survey of similar scope was also conducted in 2015. At that time, journalists from the press, radio, television, Internet broadcasters and news agencies ${ }^{8}$ most often claimed that the social reputation of the profession was 'average' (79\%), followed by 'high' (13\%), and the then 'low' (7\%). The structure of responses remained the same as in the other surveys. But in 2015, the number of responses that placed prestige at the 'average' level, in comparison to 2019, was higher by 35 percentage points. On the other hand, over four years, the number of responses reporting 'high' authority increased by 25 percentage points, and 'low' by 10 percentage points. Thus, the opinions of the surveyed journalists, who more and more often had a decided opinion on the reputation of their profession, were becoming polarised. But they expressed more often a clearly positive view of the public reputation of their profession than a clearly negative one.

The assessment of the tendency to change the perception of prestige reveals that in 2015 the majority of respondents were convinced of its decline (61\%), which is comparable to the response in $2016(59 \%)$. Only 5\% of the surveyed journalists observed an increase in respect for their profession in 2015 (a year later this figure was 14\%). Meanwhile, the 2019 research project has brought to light a clear improvement in mood: the thesis of growing authority for the profession showed a 36 percentage point increase, while the view that social authority is decreasing saw a 31 percentage point decrease.

In 2015 , the majority of the survey participants $(60 \%)$ expressed the opinion that Polish journalists are professionals. The opposite opinion was expressed by $16 \%$ of respondents. A year later, the positive assessment of the level of competence had dropped to $51 \%$, while the negative one had increased to $34 \%$. This trend was confirmed by the results of 2019, when the percentage of positive views dropped to $49 \%$, while that of negative ones rose to almost $35 \%$.

${ }^{8}$ Author's research conducted in December 2015 during a community conference in Zabrze with the participation of 60 journalists representing TV stations (including TVP 1, TVP 2, TVP Info, TVN, TVN 24, Polsat News, Superstacja, and regional branches of TVP), nationwide radio stations (including Polish Radio, RMF FM), newspapers, weekly and monthly magazines (including "Fakt" and "Forbes"), the Polish Press Agency, and Onet.pl portal. 


\section{The threat to the communication system posed by the dissemination of fake news}

The high self-esteem regarding professional competences of the journalistic community is worth correlating with the growing threat to the system of social communication involving mass media participation, which is represented by the dissemination of fake news. The majority of journalists participating in the 2019 survey claimed that information manipulation, in their opinion, is a common phenomenon. This was the position of over $57 \%$ of media professionals. Moreover, more than half of the respondents also saw this as an opportunity for traditional broadcasters who operate under the Press Law.

Journalists identified a flood of manipulation, misrepresentation and inaccuracies connected with the operation of social media — in which the author of some disseminated content can easily turn into a commentator, and where the recipient might become a reviewer and at the same time a source of further dissemination. In the opinion of journalists, the limited scope of formal tools of supervision, verification and credibility of these communications results in the possibility of increasing public trust in institutional mass media, which will distribute news prepared by journalists, applying the principles of reliability and diligence, as is required by the Press Law. Thus, a media audience may turn to professional editors in search of objective news, instead of seeking sensation amid the content that is disseminated by various types of unauthorized profiles, channels and websites.

Some of the optimism that appears in the responses of Polish journalists was shared by participants in an international research project conducted in 2019, which was aimed at determining the impact of fake news on social communication. ${ }^{9}$ Forty-four percent of them perceived a wave of information manipulation as an opportunity to regain the traditional media audience. On a global scale, however, the scope of fake news fabrication was assessed by communication experts as being much more serious than it appeared in the eyes of Polish journalists. As many as $88 \%$ of people taking part in the international project emphasized the ubiquity of fake news. What is more, unlike in national studies, $44 \%$ of respondents said the official media was also used as a tool for spreading disinformation.

9 The project was addressed to people who are partners of the association involved in the promotion of cyberspace for educational purposes. Eighteen experts from the USA, Great Britain, Pakistan and Kenya participated in the author's research project which was conducted from 26 March to 9 May 2019. 


\section{Reasons for fake news distribution by journalists}

The survey participants believed that journalists and the media employing them, for various reasons, were involved in the dissemination of manipulative news. Expressing the opinion that it poses a threat to journalism, the respondents located the reason for this practice both in phenomena affecting the internal functioning of mass media and in the interference from the external environment.

In the first category, attention was drawn to the internal sphere understood as individual and collective characteristics of journalists, including, among others, 'lack of professional education, ${ }^{10}$ 'partiality of journalists,' 'taking care of private interests at work,' 'herd reactions of journalists, who take up the suggested topics in groups,' 'poor quality of journalists' 'work,' and 'journalists' ignorance.'

Other elements of the internal sphere, these not attributed to employees of media institutions but to publishers and media owners, were the following: 'orientation on "clickability" and various forms of tabloidization,' 'transferring to the world of formal media the communication behaviors typical of social media', 'buying journalistic services by international business, which closely cooperates with global media corporations,' and(difficult to classify) 'excessive and uncontrollable freedom of the press.'

The external threat to the system of social communication, and thus to the mass media, which was most often identified involved succumbing to influence and pressure at the interface between the media and politics. ${ }^{11}$ The respondents directly called it 'politicization' or 'exerting influence on journalists by politicians,' 'political pressure on media,' and 'use of media in conflicts of political parties.' The next stage of the problem was indicated by such statements as 'progressive authoritarianism and restriction of media freedom,' 'interference of political structures in the functioning of the media,' and even 'various manifestations of censorship applied by the state'

An external threat was also perceived in the irreversibility of the changes among the media audience. These include, for example, 'the replacement of mass media with the widespread use of information drifting on the Internet'. The defensive reaction of the institutional media is to fight for the attention of the public through a greater level of tabloidization. However, it is easy to cross the border between a programme line providing the public with access to attrac-

${ }^{10}$ The material contains direct quotations from the statements of the participants in the international research project.

${ }^{11}$ It is worth mentioning a comprehensive monograph devoted to Polish journalists (from before the period of political transformation) who, despite the politicization of the media, distinguished themselves by their professionalism: J.L. CURry: Poland's Journalists: Professionalism and Politics. Cambridge 1990. 
tively prepared news and entertainment at a level acceptable to most audiences, and the colouring of reality or disinformation, which in turn may cause 'loss of press reputation due to the publication of fake news.'

\section{Forms of counteracting disinformation}

The surveyed participants of the international research project were asked to provide effective - in their opinion - forms of fighting against fake news. On this basis, it is possible to formulate a simple typology of preferred areas for corrective action that can be taken by: (1) the media, (2) the activity of state structures, (3) legal regulations, (4) communication education in order to improve media audience awareness.

The participants of the survey proposed strengthening internal control in relation to editorial structures, which concerns not only the elimination of prohibited acts committed individually by journalists (e.g. publishing false data in exchange for material or personal benefit), but also the increase in the scale of unintended errors disclosure (e.g. misrepresentations resulting from misinterpretations or ignorance of the case context) or intentional manipulations (e.g. fabrications by a source of information - in this case the editorial office is a victim). Management control should also improve the organisation of the editorial office through 'establishing and enforcing the consequences for journalists who present their opinions as facts' and 'making journalists give clear information without comments.'

The presentation of actions that can be taken by the media on their own was accompanied by declarations of the need for greater state interference in ensuring security in the process of disseminating information. Postulates in this category included improving the effectiveness of control activities and the creation of new legal regulations. These took the form of e.g. 'effective sanctions for disseminating fake news,' 'increased state control over official (institutional) media,' 'supervision of state institutions over the press, radio and television.' It was argued that 'there is a need for a stricter law to deal with entities and persons spreading fake news - not only financial sanctions, but also criminal liability.' Further statements were part of a similar form of narrative: 'strict criminal regulations should prevent journalists from being abused. Hope is to increase control over institutional media,' 'it is necessary to introduce regulations that control what is reported in the press, radio and television.' Chances to eliminate fake news from the public debate were also seen in the 'introduction of penalties for journalists abusing the freedom of speech, especially those who use lies.' This is supplemented by a similar statement: 'there should be penalties for professional journalists who knowingly abuse their rights and manipulate people using lies in the name of freedom of expression.' The authors of these as- 
sessments stressed the need for effective measures to prevent the dissemination of misrepresentation, manipulation or entirely fabricated content, even at the cost of possible restrictions on freedom of expression, which may result from excessive state interference in the freedom of the press.

The next area of counteracting disinformation should, according to the participants of the research project, be an increase in the active involvement and awareness of the media audience. This may take on a repressive form: we should 'discredit journalists responsible for fake news; they cannot enjoy authority' and 'it is necessary to disclose, show and condemn media companies that manipulate facts, especially those that are financially connected with political parties.' Recipients' actions can be reactive, in the form of 'a broad campaign counting disinformation in individual media.' They may also involve articulating expectations and taking co-responsibility for the choice of consumed content: 'The public must demand truthful information from the media. We don't have to buy newspapers that sell fake news. We do not have to listen to such radio stations or watch TV that lies. Everyone, however, must try to find different sources of information. Responsible and reliable. Or, at least, diverse. Then it is possible to get a more balanced picture of reality.' This trend includes a focus on independent, niche or civic broadcasters: 'the only hope is that readers will choose independent publishers and support journalists who are not connected with media concerns.'

Postulates addressed to the public indicate the need for media education, because 'it is important to change the way in which information is received. People should do it consciously, not passively.' You have to 'recognize the topics yourself and form your own opinions.' The following also counts: 'integration instead of polarisation. Getting to the facts together is better than trusting the information in the official media.' In this context, however, attention also must be drawn to the risks of misinformation in social media, as 'you cannot believe everything on Facebook and others' and, in the case of traditional media, 'conscious use of social media' is important.

\section{Journalistic diligence and legal limits to freedom of expression}

In analysing the results obtained in the above mentioned studies, it is worth noting a tendency to see the solution to the disinformation problem in an extension of the scope of punishable acts or increase of already existing criminal liabilities. It should be stressed that there are potential threats in actions aimed at improving the quality of public debate through the repressive elimination of untrue, manipulated or inaccurate content. The restriction of free speech is a sig- 
nificant problem. It is worth noting that in Poland the source of legal protection of free speech is the Constitution of the Republic of Poland, which states that everyone is guaranteed the freedom to express their opinions and to obtain and disseminate information. ${ }^{12}$ The same article also prohibits preventive censorship of social media and licensing of the press. As researchers emphasize, 'this provision ensures three freedoms that constitute, in the constitutional sense, the freedom of expression'. Despite the fact that the legislation did not use the term 'freedom of speech' literally, the relationship between it and the 'partial freedoms' is clearly emphasized in the provision by the jurisprudence of the Constitutional Tribunal. In the justification of the judgment of 5 May 2004 (ref. P 2/03), it was stated that 'in the Polish Constitution the principle of freedom of expression is regulated by Article 54 (1), in which three separate but related and interdependent individual freedoms are expressed. These are: freedom of expressing one's views, freedom to obtain information and freedom to disseminate information. ${ }^{13}$ However, the protection of personal rights may be a barrier to freedom of expression. It is worth mentioning that the basis for the right to legal protection of one's honour is likewise the Constitution of the Republic of Poland, in which it is written, inter alia, that inherent and inalienable human dignity is a source of freedom as well as the root of human and civil rights. It is inviolable, and its respect and protection is the duty of public authorities, ${ }^{14}$ and which also guarantees that 'everyone has the right to legal protection of private and family life, honour and good name, and to decide about his or her personal life. ${ }^{15}$ Thus, in the opinion of the Supreme Court, "the rank of both rights and the level of protection afforded to them is equal, which means that none of them may be given priority and none of them is absolute. ${ }^{16}$

Therefore, to demand the multiplication of state control systems over the mass media activities and the creation of further supervision and repression tools seems to go too far. All the more important is the fact that 'in the context of the press aims and the tasks of journalists, there are sometimes circumstances justifying the need to present certain socially important content to a wide audience, in situations that may repeal the unlawfulness of the violation of personal rights belonging to the protagonists of such publications. Freedom of expression is one of the basic foundations of a democratic society and one of the basic conditions

${ }_{12}$ Article 54, paragraph 1 of the Constitution of the Republic of Poland: The Freedom to Express Opinions, to Acquire and to Disseminate Information Shall be Ensured to Everyone. "Journal of Laws" 1997, No 78, item 483.

13 W. MoJski: Konstytucyjna ochrona wolności wypowiedzi w Polsce. Lublin 2014, p. 48.

${ }_{14}$ Article 30 of the Constitution of the Republic of Poland.

${ }_{15}$ Article 47 of the Constitution of the Republic of Poland.

${ }^{16}$ Resolution of the composition of seven judges of the Supreme Court of 18 February 2005, III CZP 53/04. Source: database of decisions of the Supreme Court portal at www.sn.pl (accessed: 26.06.2019). 
for its development and the self-fulfilment of individuals. ${ }^{37}$ It is extremely important to separate conscious disinformation from the consequences of errors in the adjudication of freedom of speech. Tools designed to both counteract and combat fake news can be effectively used to restrict freedom of expression in order to secure the rights protected by law. In extreme cases, this means a reactivation of censorship. Obviously, it is also impossible to accept uncritically the publication of press materials containing fake news, which is contrary to the statutory requirement of diligence and reliability. In the case of this type of manipulation or slander, it is worth recalling the 'position of the Supreme Court, stating that the right to criticism, which also applies to journalists, must not turn into the formulation of invective and slander against state officials. The activities of any state body may be assessed by journalists, and the public has the right to be informed about possible irregularities. This does not release a journalist from the requirement that his statements should be impartial, especially when they relate to facts. ${ }^{18}$ The need for a cautious approach to the problem of legal responses to fake news, combined with being careful in taking preventive measures by the state apparatus, as well as the strengthening of criminal liabilities, point to the enormous potential of education. These are the next spheres of possible reaction, indicated by the participants of the international research project, placed this time on the side of the media audience and press market players.

The optimization of internal editorial procedures aimed at the disclosure and elimination of fake news before its dissemination should be considered exceptionally desirable. Greater sensitivity on the part of journalists and those who decide to publish content ${ }^{19}$ can improve the situation, at least in terms of finding unintentional errors and inaccuracies more effectively. A difficulty, or even serious obstacle, in implementing this recommendation may be editorial activity which is conducted in the manner of tabloid journalism, aimed at generating sensation and emotions among the audience, since certain colorations of reality are an immanent quality of this kind of journalism. The risk of destabilising the media system posed by the prevalence of fake news could, however, affect the attitude of decision-makers in editorial offices so that they may change the rules of their functioning.

However, the greatest potential for counteracting disinformation is probably to be found on the part of the media audience. Civil opposition to the dissemination of untruth may influence business decisions made by media corporations

17 Judgment of the Court of Appeal in Łódź dated 11 June 2015. Case file I ACa 1820/14. Source: Portal Orzeczeń Sądów Powszechnych — orzeczenia.ms.gov.pl (accessed: 26.06.2019).

18 J. SobczaK: Wolność stowa w kampaniach wyborczych. Toruń 2016, p. 164.

${ }_{19}$ Pursuant to Article 7 of the Press Law, these are the editors, i.e. journalists who decide or co-decide on the publication of press materials, as well as the executive editor who has the authority to decide on the overall activity of the editorial office. 
in a much more radical way than a sense of threat to the credibility of specific editorial offices. However, social control, the stigmatisation of broadcasters who use fake news and their consequent removal from the area of used media require a high level of communication education - probably much higher than the existing one, because still in some audiences the astonishment caused even by very improbable news is tempered by the reflection that since it was given by television (press, radio, Internet portals, etc.), it certainly must contain at least a grain of truth. It cannot be ruled out, therefore, that a necessary condition for positive changes is universal communication education, which will permit news recipients to consciously trust those broadcasters who are guided by the principles of reliability and journalistic diligence.

\section{Conclusions}

The aim of the research was to determine how journalists perceive the phenomenon of the spread of disinformation. More than half of the respondents (57\%) thought that it was common. Half of the respondents found this to be a chance for traditional media. According to the majority of respondents, journalists in Poland enjoy growing social authority. On the other hand, the self-esteem of the professionalism of people working for the mass media is systematically decreasing, while the number of journalists perceiving clear shortcomings in the preparation, knowledge and competence in their group is growing. This is the result of the change of economic, technical and social conditions for practising the profession.

The development of communication technologies, the availability of new online tools for information distribution and their use on a mass scale have made it necessary for journalism to take into account in its specificity, first the existence and then the domination of cyberspace in social communication. The natural reaction was an attempt to treat the computer network as another field of exploitation for the commercial activities of media concerns. This also occurred in Poland, where "by introducing fees for access to the websites of dailies and magazines, Polish press publishers drew on the patterns from foreign ones. In 1997, New York's 'The Wall Street Journal' "20 was the first in the world to introduce a system of paid online subscriptions. However, the virtual market proved to be completely different from traditional distribution of newspapers in paid distribution networks (advertising revenue and copy sales) or free of

20 J. BogdańsKa: Płatne treści w serwisach internetowych polskiej prasy codziennej. “Acta Universitatis Lodziensis. Folia Litteraria Polonica” 2018, nr 51, p. 44. 
charge (concentration of advertising revenue), and even the functioning of radio and television broadcasters. The specificity of the computer network resulted in a potential new space for media expansion, which has become a threat to some of the existing market participants. Difficulties in achieving profitability for journalistic content available on the Internet were exacerbated by the expansion of social media. The situation in which the recipient of messages could become a reviewer or co-author of subsequent versions distributed on a computer network disturbed the previously existing models of news dissemination. The consequences of technological progress "for the organization of editorial work were not yet strongly identified and accentuated by journalists during the 2004 survey. However, the passage of time and the development of technology have meant that in 2015, convergence has already had a lasting impact on the way journalists work. ${ }^{21}$ The empowerment of so-called civic journalism and the growth of its social scope were further factors that have influenced the position of professional workers and media collaborators.

The conditions for working as a journalist must also be looked at from a broader perspective. ${ }^{22}$ An editorial staff member is subject to various consequences of the convergence process, which may take the form of preparing press releases in multimedia versions, announcing and commenting on them in social media, participating in feedback management, etc. One effect of ownership concentration in the media is a decrease in the financial appeal of this profession (e.g. by the employer taking over copyright to works published in other fields of media belonging to the publisher), and 'pressure exerted on journalists (mainly economic), reduction of social rights and limitation of independence these are problems occurring in all editorial offices. It seems that also the owners of media and the management of the editorial office, through their attitude, contribute to depriving journalism of the features of the creative profession. ${ }^{23}$ These factors are not unrelated to the perception of the social reputation that the profession enjoys. What is more, current law does not provide for 'a requirement for journalists to have a university degree or a practical training, as evidenced by a professional practice. In the light of literature, such education and training is essential for professionals. It seems that the journalist's profession in Poland is at a certain crossroads and it will either fall to the position of an intellectu-

${ }^{21}$ D. KrawczyK: Zmiany $w$ spolecznym postrzeganiu prestiżu zawodu dziennikarza wobec przeksztatceń rynku medialnego. W: Teorie komunikacji i mediów. T. 9: Konstrukcje komunikacji mediów. Red. M. Graszewicz, M. WszoŁeK. Wrocław 2016, p. 239.

${ }^{22}$ The conditions of contemporary journalism have been described in, among others, the following publication: Journalistic Role Performance: Concepts, Contexts, and Methods (Routledge Research in Journalism). Eds. C. Mellado, L. Hellmueller, W. Donsbach (d. 2015). New York 2017.

${ }^{23}$ L. Szot: Wartości i standardy zawodowe dziennikarza. "Zeszyty Prasoznawcze" 2016, nr 2 (226), p. 389. 
ally efficient hired employee, giving up his or her abilities to an employer, ready to create in accordance with his or her instructions and guidelines, or become a free profession of public trust. ${ }^{24}$ At present, for some candidates, this profession is unattractive due to the need for journalists to be constantly available, the need for significant involvement in the work, the need to acquire competence to operate communication tools and the average level of remuneration. However, for those who perform it, it may be interesting, intriguing, developing, and satisfying, and it might ensure social recognition. This is confirmed by the results of the self-evaluation carried out by journalists. Research into the prestige of the profession revealed a consistent increase in the number of people who believe in its high level (from $13 \%$ in 2015, through $17 \%$ in 2016 to $38 \%$ in 2019, i.e. an increase of 25 percentage points), although there was also an increase in the number of people declaring a decline in social recognition (from 7\% in 2015, through $11 \%$ in 2016 to $17 \%$ in 2019 , but this change reached only 10 percentage points). This was at the expense of a decline in the group of media employees who considered their profession's reputation to be average (from $79 \%$ in 2015 , through $71 \%$ in 2016 to $44 \%$ in 2019 ).

Clear tendencies were also observed in the evaluation of the directions of changes in the prestige of the journalist's profession. The percentage of respondents who indicate the increasing authority of the profession is growing (from 5\% in 2015 , through $14 \%$ in 2016 , to $41 \%$ in 2019 , i.e. an increase of 36 percentage points); and the number of reporters who indicate a decreasing prestige is falling (from $61 \%$ in 2015 , through $59 \%$ in 2016 , to $38 \%$ in 2019 , i.e. a decrease of 23 percentage points).

There was also a disturbing, yet consistent decrease in the number of surveyed journalists who indicated that their fellow-journalists are professionals (from $60 \%$ in 2015 , through $51 \%$ in 2016 to $49 \%$ in 2019, i.e. a decrease of 11 percentage points). And claims of a lack of adequate level of competence to perform this profession correspondingly increased (from 16\% in 2015, through $34 \%$ in 2016, to 35\% in 2019, an increase of 19 percentage points). Data concerning the assessment of journalists' professionalism should also be included in the need to undertake actions aimed at improving the quality of social communication systems which are currently struggling with the problem of disinformation dissemination. The need to initiate a broad educational program is suggested by an opinion poll on the scale of disinformation in the mass media and social media, conducted among students of journalism and social communication in 2019. ${ }^{25}$ Survey participants, although in most cases not active on the media mar-

24 J. Sobczak, K. Kakareko: Zawód dziennikarza w obliczu zmian. "Zeszyty Naukowe KUL" 2017, nr 1, p. 133.

${ }_{25}$ The research into the perception of disinformation was addressed to all students of the last year's full-time studies in social communication and journalism at the University of Silesia in Katowice. It was conducted on 16 May 2019. It was attended by 54 students. 
ket, due to their education should have a solid knowledge of the rules and conditions of mass communication. As many as $76 \%$ of them declared that the scale of making fake news available is really large. Fifty-five percent of respondents, representing a group of exceptionally conscious recipients of media messages, were convinced of its destructive impact on the functioning and credibility of traditional editorial offices.

\section{Bibliography}

BogdańsKa J.: Platne treści w serwisach internetowych polskiej prasy codziennej. "Acta Universitatis Lodziensis. Folia Litteraria Polonica" 2018, nr 51.

Curry J.L.: Poland's Journalists: Professionalism and Politics. Cambridge 1990.

Dictionary of the Polish Language PWN — https://sjp.pwn.pl (accessed: 6.03.2019).

Dobek-Ostrowska B., Barczyszyn P., Michel A.: The Change in Journalism. Professional Culture of Polish Journalists (quantitative research). "Media Studies" 2013, no. 1.

Dobek-Ostrowska B.: Polski system medialny na rozdrożu. Media w polityce, polityka w mediach. Wrocław 2011.

Journalistic Role Performance: Concepts, Contexts, and Methods (Routledge Research in Journalism). Eds. C. Mellado, L. Hellmueller, W. Donsbach (d. 2015). New York 2017.

Judgment of the Court of Appeal in Łódź dated 11 June 2015. Case file I ACa 1820/14. Source: Portal Orzeczeń Sądów Powszechnych — orzeczenia.ms.gov. pl (accessed: 26.06.2019).

KraWCZyK D.: Zmiany w spolecznym postrzeganiu prestizu zawodu dziennikarza wobec przeksztatceń rynku medialnego. W: Teorie komunikacji i mediów. T. 9: Konstrukcje komunikacji mediów. Red. M. Graszewicz, M. WszoŁeK. Wrocław 2016.

MoJsKI W.: Konstytucyjna ochrona wolności wypowiedzi w Polsce. Lublin 2014.

OlęDZKi J.: Polish Journalists: Professionals or Not? In: The Global Journalist. News People Around the World. Eds. D.H. Weaver, W. Wu. New York 1998.

Resolution of the Composition of Seven Judges of the Supreme Court of 18 February 2005, III CZP 53/04. Source: database of decisions of the Supreme Court portal at www.sn.pl (accessed: 26.06.2019).

SobczaK J., KaKareKo K.: Zawód dziennikarza w obliczu zmian. "Zeszyty Naukowe KUL” 2017, nr 1.

SobCZAK J.: Wolność stowa w kampaniach wyborczych. Torun 2016.

Szot L.: Wartości i standardy zawodowe dziennikarza. "Zeszyty Prasoznawcze" 2016, nr 2 (226).

The Act of 26 January 1984, the Press Law is the Scope of the Journalist's Duties. "Journal of Laws" 1984, No 5, item 24. 
The Constitution of the Republic of Poland "Journal of Laws" 1997, No 78, item 483.

Dariusz Krawczyk, Ph.D., is a member of the Polish Communication Association, member of the Committee on Organizational and Management Sciences of the Polish Academy of Sciences in Katowice, expert witness in social communication and management, and Head of the Social Contacts Department in the City Hall in Zabrze. 